\title{
Volume and Aboveground Biomass Models for Dry Miombo Woodland in Tanzania
}

\author{
Ezekiel Edward Mwakalukwa, ${ }^{1,2}$ Henrik Meilby, ${ }^{1}$ and Thorsten Treue ${ }^{1}$ \\ ${ }^{1}$ Department of Food and Resource Economics, Faculty of Science, University of Copenhagen, Rolighedsvej 23, \\ 1958 Frederiksberg C, Denmark \\ ${ }^{2}$ Department of Forest Biology, Faculty of Forestry and Nature Conservation, Sokoine University of Agriculture, P.O. Box 3010, \\ Chuo Kikuu, Morogoro, Tanzania
}

Correspondence should be addressed to Ezekiel Edward Mwakalukwa; ezedwa@yahoo.com

Received 7 March 2014; Accepted 14 April 2014; Published 22 May 2014

Academic Editor: Guy R. Larocque

Copyright (C) 2014 Ezekiel Edward Mwakalukwa et al. This is an open access article distributed under the Creative Commons Attribution License, which permits unrestricted use, distribution, and reproduction in any medium, provided the original work is properly cited.

\begin{abstract}
Tools to accurately estimate tree volume and biomass are scarce for most forest types in East Africa, including Tanzania. Based on a sample of 142 trees and 57 shrubs from a 6,065 ha area of dry miombo woodland in Iringa rural district in Tanzania, regression models were developed for volume and biomass of three important species, Brachystegia spiciformis Benth. $(n=40)$, Combretum molle G. Don $(n=41)$, and Dalbergia arbutifolia Baker $(n=37)$ separately, and for broader samples of trees $(28$ species, $n=72$ ), shrubs (16 species, $n=32$ ), and trees and shrubs combined (44 species, $n=104$ ). Applied independent variables were log-transformed diameter, height, and wood basic density, and in each case a range of different models were tested. The general tendency among the final models is that the fit improved when height and wood basic density were included. Also the precision and accuracy of the predictions tended to increase from general to species-specific models. Except for a few volume and biomass models developed for shrubs, all models had $R^{2}$ values of $96-99 \%$. Thus, the models appear robust and should be applicable to forests with similar site conditions, species, and diameter ranges.
\end{abstract}

\section{Introduction}

Standing volume and aboveground biomass (AGB) are the two main measures of forest stocking that are typically considered within the framework of sustainable forest management and for carbon accounting purposes $[1,2]$. Accurate estimation of tree volume and forest biomass is not only crucial for assessing expected yields from commercial and subsistence harvesting. It is also important for carbon storage assessment in relation to global climate change mitigation measures [3, 4]. For this purpose, forest biomass can be applied to estimate carbon stocks and carbon fluxes when measured repeatedly, thus providing means for estimating the amount of carbon dioxide released into or removed from the atmosphere.

However, direct measurement of volume and AGB is time consuming, costly, and usually destructive by nature. Therefore, the general practice is to estimate volume and AGB from tree dendrometric characteristics such as diameter and height, using established, general, or site-specific allometric equations $[1,3,5,6]$. The selection of an appropriate allometric equation is a key element in the accurate estimation of forest yield and stand productivity as well as carbon stocks and changes in stocks $[7,8]$. Unfortunately, such equations often produce biased results when applied outside the forest area or region where they were developed. If high accuracy is required for quantification and verification of a particular forest's carbon storage or for other management purposes, it is therefore recommended to develop local biomass and volume equations or at least to harvest and measure a few trees, representing the range of tree sizes typically found in the forest, and use these to check the validity of the applied equation under local conditions $[1,9,10]$.

In eastern, central, and southern Africa, where miombo woodland is the principal vegetation type, only few studies of this nature have been conducted and tools for accurate 
estimation of forest volume and biomass and for carbon accounting purposes are generally lacking [10-12]. In Tanzania, two studies have developed biomass models using data from a relatively dry miombo woodland site at Kitulanghalo Forest Reserve in Morogoro Region, eastern Tanzania, which receives an annual rainfall of about $900 \mathrm{~mm} \mathrm{year}^{-1}[13,14]$. These studies were conducted on the basis of a very limited sample size ( $<30$ trees) covering a narrow diameter range $(1.1-50 \mathrm{~cm})$. Recent work by Mugasha et al. [15] covers a wider range of sites (four dry and one wet miombo sites). Yet it only includes a few more trees per site in the three relatively dry miombo woodland sites, 40 trees in Manyara Region, northeastern Tanzania ( $854 \mathrm{~mm}$ year $^{-1}$ ), 40 trees in Katavi Region, western Tanzania $\left(881 \mathrm{~mm} \mathrm{year}^{-1}\right)$, and 40 trees in Tabora Region, western central Tanzania $(771 \mathrm{~mm}$ year $^{-1}$ ). In addition, the number of species used in developing site-specific models was very low, for example, 10 species for the Manyara site, but the general, countrywide model had adequate species richness ( $>45$ different species). Having included trees from wet miombo sites which have different growth habits compared to those found in typical dry miombo areas and considering the large site differences across miombo woodlands with respect to climate, soil, altitude, land form, species composition, and historical land use, there appears to be a strong need for developing models for sites that receive very little precipitation, such as the areas in Iringa Region, south central Tanzania, (617 $\left.\mathrm{mm} \mathrm{year}^{-1}\right)$ to increase the accuracy of predicted stand volume, biomass, and carbon stock in such site types.

Miombo woodlands consist of open, light stands of a deciduous or semideciduous nature, with up to three vegetation strata, upper canopy trees, secondary layer (including the shrub layer, $<8 \mathrm{~m}$ tall), and herbaceous layer which consists chiefly of grasses up to $2 \mathrm{~m}$ tall [16]. The upper canopy trees can reach heights of 14-20 $\mathrm{m}$ while trees of the secondary layer may reach $8-12 \mathrm{~m}$. Understory shrubs are multistemmed due to fire or stem cutting and tend to cover up to $70 \%$ of the ground. This vegetation is an important source of fuel wood for the majority of people living in miombo areas and, due to the large areas that it covers, the carbon stocks and sequestration potential of the woodland are high $[17,18]$. Unfortunately, previous studies in the miombo did not include biomass models for understory species (shrubs) [13-15].

Although with some limitations due to the large number of species in tropical forests, species-specific volume and biomass models are often preferred for accurate estimation of forest volume and biomass and for carbon accounting purposes $[19,20]$. This type of models has been developed for a wide range of plantation species and in temperate regions where the number of relevant tree species is lower. However, most types of tropical vegetation are characterized by dominant species, so it has been suggested to develop a database of allometric equations for selected dominant tree species which are particularly important for volume and biomass estimates as they contribute a large proportion of the biomass compared to other species [21]. In Tanzania, species-specific volume functions have been prepared for a few dominant miombo species in Tabora in the western part of the country $[22,23]$ and elsewhere [24]. These studies were, however, also based on a very small sample size $(<27)$ and a narrow diameter range $(<43 \mathrm{~cm})$.

Wood density is a key variable in the estimation of tree biomass $[25,26]$. However, none of the above studies have reported biomass models, which take into account the contribution of wood basic density in explaining the variation in tree/shrub biomass. Inclusion of wood density in biomass modelling has been shown to improve the performance of the models significantly $[25,26]$.

Accordingly, the objectives of this study were to (1) develop volume and AGB allometric equations for three dominant species (Brachystegia spiciformis Benth., Combretum molle G. Don, and Dalbergia arbutifolia Baker) and (2) develop general equations for three life form groups: trees, shrubs, and woody species in general (trees and shrubs combined). The new models will not only help increase our knowledge on total aboveground productivity of miombo woodlands but also support planning, assessment, and development of management strategies for sustainable utilization of the woodlands. Furthermore, the local biomass models developed in this paper will not only add to existing knowledge about the miombo but also support the nation of Tanzania in accurate estimation and reporting of current forest biomass stocks and their changes over time.

\section{Materials and Methods}

2.1. Study Site. Gangalamtumba Village Land Forest Reserve (GVLFR) is located in central-southern Tanzania $\left(7^{\circ} 35^{\prime} \mathrm{S}\right.$, $35^{\circ} 35^{\prime} \mathrm{E}$ ), about $30 \mathrm{~km}$ northwest of Iringa Municipality, the administrative capital of Iringa Region (Figure 1). The area of the forest is 6,065 hectares and it is managed by the Mfyome village, which is located in the ward of Kiwele. The forest can be described as dry miombo woodland and the terrain is relatively flat and located $850-1,300$ metres above sea level. The average annual rainfall is (mean \pm standard error) $617 \pm 17 \mathrm{~mm}$ (range: $448-1,085 \mathrm{~mm}$ ) and the mean annual temperature is $19.8^{\circ} \mathrm{C}$. The soil texture ranges from sandy soils at low elevations to sandy clay loams at higher elevations with $\mathrm{pH}$ from 5.7 to 8.7. GVLFR is a production forest which allows some commercial forest activities, including charcoal production, firewood collection, and livestock grazing mainly during the dry season.

2.2. Field Sampling. The survey was conducted in August 2009 and September-October 2010 and involved harvesting of 142 individual trees (28 species) and 57 individual shrubs (16 species) from a $30 \mathrm{~m}$ wide boundary zone of 35 permanent circular sample plots with a radius of $50 \mathrm{~m}$ ( $0.7854 \mathrm{ha})$ that were distributed across the entire area of the GVLFR (Figure 1). Plots were located along transect lines and the distance between plots was about $2 \mathrm{~km}$. The centre points of the plots are identical to those used in a survey that was previously conducted in the forest [27]. The minimum and maximum sizes of sample trees/shrubs were $1.4 \mathrm{~cm}$ and $62.0 \mathrm{~cm}$ in diameter at breast height (Dbh), respectively. For 


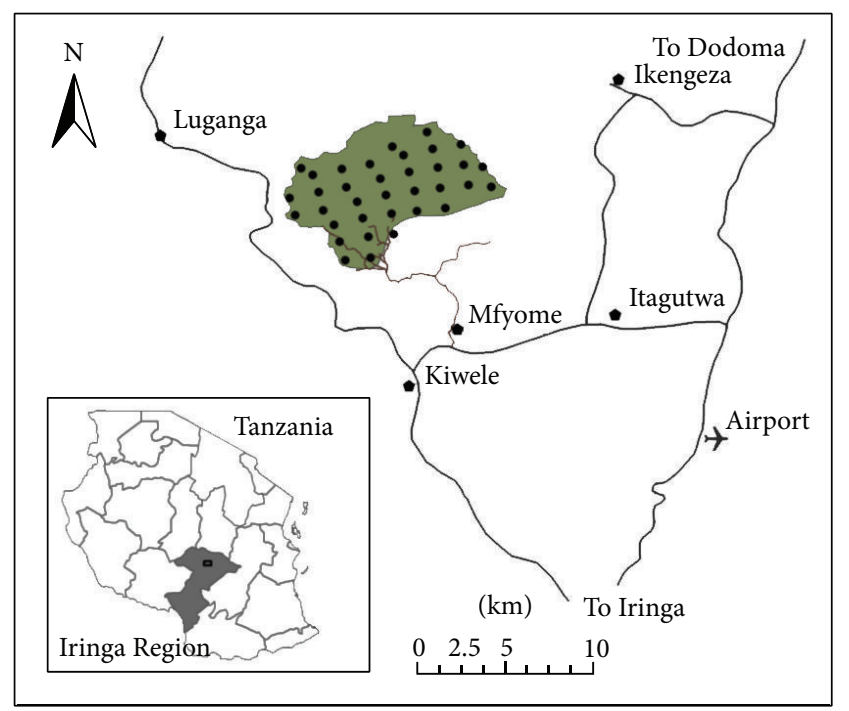

$\begin{array}{llll}- & \text { Plots } & - & \text { Forest roads } \\ & \text { Villages } & \square & \text { Gangalamtumba forest reserve } \\ \text { Dirt roads } & \square & \end{array}$

FIgURE 1: Map of the study area and its location in Iringa Region, Tanzania.

each tree or shrub felled, the following measurements were made: stump diameter $20 \mathrm{~cm}$ above ground, Dbh, crown radius in four directions (north, south, west, and east), height to first branch, and total height. Diameter was measured to the nearest $0.1 \mathrm{~cm}$ using a diameter tape, height was measured using a Suunto clinometer, and crown width was measured to the nearest $0.01 \mathrm{~m}$ by tape measure. Species were identified by a local botanist using vernacular names in the Hehe language. Scientific identification was done by a botanist from the herbarium centre at the Silviculture Research Station in Lushoto, which is part of Tanzania Forest Research Institute (TAFORI). In cases where it proved difficult to identify a species in the field, voucher specimens were collected and sent to the herbarium in Lushoto for identification.

Based on their estimated relative basal area, 44 species (both trees and shrubs) were selected as a representative sample of the most common species. This selection was meant to cover the widest possible range of diameter classes as recommended by, for example, Brown [1] and Husch et al. [3]. Furthermore, to distribute the sample across the forest, at least 3 trees and 2 shrubs were felled within each of the 35 plots. To support data quality checking and error correction, a sketch of the crown structure of each tree/shrub was prepared in the field and used for marking points of cross-cutting. Generally, the choice of upper diameter limit depends on the utilisation of the wood. In this region an important use of the wood is for charcoal production and few tree species are used for timber production. The typical top diameter applied by charcoal makers in the area appears to be $5 \mathrm{~cm}$, and we therefore prepared models for total volume and biomass and for commercial volume of stems with diameter $\geq 5 \mathrm{~cm}$.
In the field, small branches with diameter less than $5 \mathrm{~cm}$ were first removed, tied into bundles (piles), and weighed (fresh weight). Subsamples of these piles were selected and brought to the laboratory for dry weight determination. For each tree/shrub, five disks with a thickness of about $2-3 \mathrm{~cm}$ were sampled from the remaining part of the tree/shrub ( $\geq 5 \mathrm{~cm}$ diameter). These were used for basic density estimation and their green/fresh weight was measured in the field. Selection of the five disks was based on importance sampling, for example, $[5,28]$, implying that the selection of tree sections in which the disks were to be extracted depended on the estimated proportion of volume in each section (probability of selection proportional to volume). This method has been found to yield relatively good results with minimal errors and bias compared to the conventional method of sectional weight measurements in the field, which is often costly in terms of labour and time [5].

2.3. Laboratory Analyses. In the laboratory, all subsamples for twigs/branches $<5 \mathrm{~cm}$ (crown wood) and disks extracted from stem and branch sections were oven dried at $103 \pm 2^{\circ} \mathrm{C}$ to constant weight. Dried samples were weighed and the biomass ratio for each pile of twigs/branches was computed as the ratio of oven-dry weight to green weight $[5,13]$. Green volume of the sample disks was obtained after soaking the disks in water for at least four days until they were saturated. Using the water displacement method, the volume of each disk was determined $[1,29]$. Basic density $\left(\mathrm{g} \mathrm{cm}^{-3}\right)$ for each disk was determined as the ratio of dry weight $(\mathrm{g})$ to green volume $\left(\mathrm{cm}^{3}\right)$.

2.4. Data Preparation. For each tree, the stump volume was calculated using the cylinder formula and the volume of stem sections and branches with diameter $\geq 5 \mathrm{~cm}$ was calculated using Newton's formula. The volume of twigs/branches $<5 \mathrm{~cm}$ in diameter was estimated using their estimated biomass and the estimated basic density [30]. Commercial volume $\geq 5 \mathrm{~cm}$ was estimated as the sum of stump volume and the volumes of stem and branch sections to $5 \mathrm{~cm}$ top diameter. Total volume was calculated by adding the estimated volume of branches $<5 \mathrm{~cm}$ to the commercial volume. This dataset was used for developing volume models for each group of species: (1) $B$. spiciformis, (2) C. molle, (3) D. arbutifolia, (4) shrubs/small trees, (5) trees, and (6) all species (trees and shrubs).

Biomass $(\mathrm{kg})$ was calculated as the product of density $\left(\mathrm{kg} \mathrm{m}^{-3}\right)$ and volume $\left(\mathrm{m}^{3}\right)$ for stem and branch sections $[5,28]$. For twigs and leaves, biomass was estimated as the product of estimated biomass ratio (dry to green weight of subsamples) and total green weight $(\mathrm{kg})$ of the pile measured in the field. The total aboveground biomass for each tree was obtained as the sum of stump biomass, biomass of stem and branch sections, and biomass of twigs and leaves. The resulting dataset was used for developing biomass models for each of the six species groups mentioned above.

2.5. Statistical Analysis. Like in other studies $[3,13,31]$ several linear models with different transformations were tested during the development of volume and biomass models. 
TABLE 1: Volume and biomass equations ${ }^{\dagger}$ for estimating total aboveground and stem $(\geq 5 \mathrm{~cm})$ volume and biomass of three dominant species in the Gangalamtumba Village Land Forest Reserve. All parameter estimates are significantly different from zero $(P<0.001)$.

\begin{tabular}{|c|c|c|c|c|c|c|c|c|c|}
\hline \multirow{2}{*}{ Species } & \multirow{2}{*}{ Component } & \multirow{2}{*}{ Equation $^{\dagger}$} & \multicolumn{3}{|c|}{ Regression parameters } & \multirow{2}{*}{ Dbh range $(\mathrm{cm})$} & \multirow{2}{*}{ Adj. $R^{2}$} & \multirow{2}{*}{ RMSE } & \multirow{2}{*}{ Avg. error (\%) } \\
\hline & & & $a$ & $b$ & $c$ & & & & \\
\hline \multirow{9}{*}{$\begin{array}{l}\text { Brachystegia } \\
\text { spiciformis } \\
(N=40)\end{array}$} & $\begin{array}{l}\text { Total volume } \\
\quad(\mathrm{df}=37)\end{array}$ & 3 & $\begin{array}{c}-9.3188 \\
(0.166)\end{array}$ & $\begin{array}{l}1.9663 \\
(0.088)\end{array}$ & $\begin{array}{l}0.9118 \\
(0.174)\end{array}$ & $1.2-54.3$ & 0.997 & 0.142 & 1.99 \\
\hline & $(\mathrm{df}=38)$ & 4 & $\begin{array}{c}-8.5018 \\
(0.077)\end{array}$ & $\begin{array}{c}2.4142 \\
(0.027)\end{array}$ & - & $1.2-54.3$ & 0.995 & 0.185 & 3.49 \\
\hline & $\begin{array}{l}\text { Stem volume } \\
\qquad(\mathrm{df}=31)\end{array}$ & 3 & $\begin{array}{c}-11.7673 \\
(0.379)\end{array}$ & $\begin{array}{l}2.0335 \\
(0.141)\end{array}$ & $\begin{array}{l}1.6858 \\
(0.314)\end{array}$ & $5-54.3$ & 0.990 & 0.209 & -0.02 \\
\hline & $(\mathrm{df}=32)$ & 4 & $\begin{array}{c}-9.8909 \\
(0.203)\end{array}$ & $\begin{array}{l}2.7460 \\
(0.066)\end{array}$ & - & $5-54.3$ & 0.981 & 0.286 & 2.14 \\
\hline & $\begin{array}{l}\text { Total biomass } \\
\quad(\mathrm{df}=37)\end{array}$ & 3 & $\begin{array}{c}-2.6071 \\
(0.149)\end{array}$ & $\begin{array}{l}2.0638 \\
(0.078)\end{array}$ & $\begin{array}{l}0.7847 \\
(0.155)\end{array}$ & $1.2-54.3$ & 0.998 & 0.127 & 1.60 \\
\hline & $(\mathrm{df}=38)$ & 4 & $\begin{array}{c}-1.9040 \\
(0.068)\end{array}$ & $\begin{array}{l}2.4492 \\
(0.024)\end{array}$ & - & $1.2-54.3$ & 0.996 & 0.162 & 2.67 \\
\hline & $(\mathrm{df}=38)$ & 6 & $\begin{array}{c}-9.3309 \\
(0.108)\end{array}$ & $\begin{array}{c}0.9827 \\
(0.008)\end{array}$ & - & $1.2-54.3$ & 0.998 & 0.127 & 1.66 \\
\hline & $\begin{array}{l}\text { Stem biomass } \\
\quad(\mathrm{df}=31)\end{array}$ & 3 & $\begin{array}{c}-5.0668 \\
(0.343)\end{array}$ & $\begin{array}{l}2.1424 \\
(0.128)\end{array}$ & $\begin{array}{l}1.5563 \\
(0.284)\end{array}$ & $5-54.3$ & 0.992 & 0.189 & -0.57 \\
\hline & $(\mathrm{df}=32)$ & 4 & $\begin{array}{c}-3.3345 \\
(0.185) \\
\end{array}$ & $\begin{array}{l}2.8002 \\
(0.061) \\
\end{array}$ & - & $5-54.3$ & 0.985 & 0.262 & 1.17 \\
\hline \multirow{9}{*}{$\begin{array}{l}\text { Combretum } \\
\text { molle } \\
(N=41)\end{array}$} & $\begin{array}{l}\text { Total volume } \\
\quad(\mathrm{df}=38)\end{array}$ & 3 & $\begin{array}{c}-9.0504 \\
(0.165)\end{array}$ & $\begin{array}{c}1.9212 \\
(0.099)\end{array}$ & $\begin{array}{l}0.7712 \\
(0.183)\end{array}$ & $2.2-26.5$ & 0.987 & 0.171 & 2.90 \\
\hline & $(\mathrm{df}=39)$ & 4 & $\begin{array}{c}-8.5247 \\
(0.130)\end{array}$ & $\begin{array}{l}2.2972 \\
(0.051)\end{array}$ & - & $2.2-26.5$ & 0.981 & 0.204 & 4.24 \\
\hline & $\begin{array}{l}\text { Stem volume } \\
\qquad(\mathrm{df}=30)\end{array}$ & 3 & $\begin{array}{c}-10.3990 \\
(0.223)\end{array}$ & $\begin{array}{l}2.0420 \\
(0.126)\end{array}$ & $\begin{array}{l}1.0908 \\
(0.193)\end{array}$ & $5-26.5$ & 0.977 & 0.146 & 4.64 \\
\hline & $(\mathrm{df}=31)$ & 4 & $\begin{array}{c}-9.8028 \\
(0.277)\end{array}$ & $\begin{array}{l}2.6237 \\
(0.102)\end{array}$ & - & $5-26.5$ & 0.954 & 0.206 & 4.98 \\
\hline & $\begin{array}{l}\text { Total biomass } \\
\quad(\mathrm{df}=38)\end{array}$ & 3 & $\begin{array}{c}-2.4539 \\
(0.165)\end{array}$ & $\begin{array}{l}1.9685 \\
(0.099)\end{array}$ & $\begin{array}{l}0.7545 \\
(0.183)\end{array}$ & $2.2-26.5$ & 0.987 & 0.170 & 2.88 \\
\hline & $(\mathrm{df}=39)$ & 4 & $\begin{array}{c}-1.9395 \\
(0.129)\end{array}$ & $\begin{array}{l}2.3364 \\
(0.050)\end{array}$ & - & $2.2-26.5$ & 0.982 & 0.203 & 4.20 \\
\hline & $(\mathrm{df}=39)$ & 6 & $\begin{array}{c}-8.8347 \\
(0.230)\end{array}$ & $\begin{array}{l}0.9371 \\
(0.168)\end{array}$ & - & $2.2-26.5$ & 0.987 & 0.170 & 2.98 \\
\hline & $\begin{array}{l}\text { Stem biomass } \\
\qquad(\mathrm{df}=30)\end{array}$ & 3 & $\begin{array}{c}-3.7737 \\
(0.230)\end{array}$ & $\begin{array}{c}2.1112 \\
(0.130)\end{array}$ & $\begin{array}{l}1.0410 \\
(0.199)\end{array}$ & $5-26.5$ & 0.976 & 0.151 & 4.41 \\
\hline & $(\mathrm{df}=31)$ & 4 & $\begin{array}{c}-3.2047 \\
(0.275)\end{array}$ & $\begin{array}{l}2.6663 \\
(0.101)\end{array}$ & - & $5-26.5$ & 0.956 & 0.205 & 4.66 \\
\hline \multirow{6}{*}{$\begin{array}{l}\text { Dalbergia } \\
\text { arbutifolia } \\
(N=37)\end{array}$} & $\begin{array}{l}\text { Total volume } \\
\quad(\mathrm{df}=34)\end{array}$ & 3 & $\begin{array}{c}-9.3147 \\
(0.191)\end{array}$ & $\begin{array}{c}1.9701 \\
(0.059)\end{array}$ & $\begin{array}{l}0.8854 \\
(0.152)\end{array}$ & $1.8-21.5$ & 0.991 & 0.144 & 2.04 \\
\hline & $(\mathrm{df}=35)$ & 4 & $\begin{array}{c}-8.3253 \\
(0.120)\end{array}$ & $\begin{array}{l}2.2413 \\
(0.051)\end{array}$ & - & $1.8-21.5$ & 0.982 & 0.200 & 3.90 \\
\hline & $\begin{array}{l}\text { Stem volume } \\
\qquad(\mathrm{df}=29)\end{array}$ & 3 & $\begin{array}{c}-13.8803 \\
(0.761)\end{array}$ & $\begin{array}{c}2.0113 \\
(0.246)\end{array}$ & $\begin{array}{l}2.7732 \\
(0.455)\end{array}$ & $5-21.5$ & 0.871 & 0.355 & 12.97 \\
\hline & $(\mathrm{df}=30)$ & 4 & $\begin{array}{c}-10.5743 \\
(0.793)\end{array}$ & $\begin{array}{l}2.7785 \\
(0.313)\end{array}$ & - & $5-21.5$ & 0.715 & 0.528 & 32.87 \\
\hline & $\begin{array}{l}\text { Total biomass } \\
\quad(\mathrm{df}=34)\end{array}$ & 3 & $\begin{array}{c}-2.7097 \\
(0.199)\end{array}$ & $\begin{array}{l}1.9900 \\
(0.062)\end{array}$ & $\begin{array}{l}0.9035 \\
(0.159)\end{array}$ & $1.8-21.5$ & 0.990 & 0.150 & 1.22 \\
\hline & $(\mathrm{df}=35)$ & 4 & $\begin{array}{c}-1.7001 \\
(0.124)\end{array}$ & $\begin{array}{l}2.2667 \\
(0.052)\end{array}$ & - & $1.8-21.5$ & 0.981 & 0.206 & 3.00 \\
\hline
\end{tabular}


TABle 1: Continued.

\begin{tabular}{|c|c|c|c|c|c|c|c|c|c|}
\hline \multirow{2}{*}{ Species } & \multirow{2}{*}{ Component } & \multirow{2}{*}{ Equation $^{\dagger}$} & \multicolumn{3}{|c|}{ Regression parameters } & \multirow{2}{*}{ Dbh range $(\mathrm{cm})$} & \multirow[t]{2}{*}{ Adj. $R^{2}$} & \multirow[t]{2}{*}{ RMSE } & \multirow[t]{2}{*}{ Avg. error (\%) } \\
\hline & & & $a$ & $b$ & $c$ & & & & \\
\hline & $(\mathrm{df}=35)$ & 6 & $\begin{array}{c}-9.3782 \\
(0.213)\end{array}$ & $\begin{array}{l}0.9823 \\
(0.016)\end{array}$ & - & $1.8-21.5$ & 0.990 & 0.148 & 1.37 \\
\hline & $\begin{array}{l}\text { Stem biomass } \\
\quad(\mathrm{df}=29)\end{array}$ & 3 & $\begin{array}{c}-7.3073 \\
(0.776)\end{array}$ & $\begin{array}{l}2.0138 \\
(0.250)\end{array}$ & $\begin{array}{l}2.8503 \\
(0.464)\end{array}$ & $5-21.5$ & 0.869 & 0.362 & 11.53 \\
\hline & $(\mathrm{df}=30)$ & 4 & $\begin{array}{c}-3.9094 \\
(0.812)\end{array}$ & $\begin{array}{l}2.8023 \\
(0.321)\end{array}$ & - & $5-21.5$ & 0.708 & 0.541 & 30.54 \\
\hline & $(\mathrm{df}=30)$ & 6 & $\begin{array}{c}-14.5150 \\
(1.467)\end{array}$ & $\begin{array}{l}1.2961 \\
(0.108)\end{array}$ & - & $5-21.5$ & 0.823 & 0.421 & 17.00 \\
\hline
\end{tabular}

Note: numbers in brackets indicate standard errors of the parameter estimates. Height (range): B. spiciformis: 2-17.2 m; C. molle: 2.6-9.4 m; and D. arbutifolia: $2.6-8.8 \mathrm{~m}$. df is degrees of freedom; RMSE is the standard error of the residuals; Adj. $R^{2}$ is the adjusted coefficient of determination; Avg. is Average. ${ }^{\dagger}$ Equation (3): $\ln (Y)=a+b \ln (\mathrm{Dbh})+c \ln (\mathrm{ht})$. Equation (4): $\ln (Y)=a+b \ln (\mathrm{Dbh})$. Equation (6): $\ln (Y)=a+b \ln \left(\mathrm{wdDbh}^{2} \mathrm{ht}\right) ; Y$ is volume $\left(\mathrm{m}^{3}\right)$ or biomass (kg); Dbh is diameter at breast height $(\mathrm{cm})$; ht is total height $(\mathrm{m})$; and wd is wood density $\left(\mathrm{kg} \mathrm{m}^{-3}\right)$.

The following general model formulations with logarithmic transformation of dependent and independent variables were tested:

$$
\begin{aligned}
& \text { (1) } \ln (Y)=a+b \times \ln (\mathrm{Dbh})+c \times \ln \left(\mathrm{Dbh}^{2}\right)+d \times \ln (\mathrm{ht})+ \\
& \quad e \times \ln \left(\mathrm{ht}^{2}\right) \\
& \text { (2) } \ln (Y)=a+b \times \ln \left(\mathrm{Dbh}^{2} \mathrm{ht}\right) \\
& \text { (3) } \ln (Y)=a+b \times \ln (\mathrm{Dbh})+c \times \ln (\mathrm{ht}) \\
& \text { (4) } \ln (Y)=a+b \times \ln (\mathrm{Dbh})
\end{aligned}
$$

For species-specific volume and biomass models, we used ordinary least squares estimation, assuming that errors were normally and independently distributed, whereas models for groups of species (i.e., trees, shrubs, and both groups combined) were prepared using the following mixed linear model formulation:

$$
\text { (5) } \ln (Y)_{i j}=f\left(\mathrm{Dbh}_{i j}, \mathrm{ht}_{i j}\right)+v_{i}+\varepsilon_{i j} \text {. }
$$

In all models, $Y$ is volume $\left(\mathrm{m}^{3}\right.$ tree $\left.{ }^{-1}\right)$ or biomass $\left(\mathrm{kg} \mathrm{tree}^{-1}\right)$; Dbh is diameter at breast height $(\mathrm{cm})$ and ht is total height of the tree/shrub (m); $a, b, c, d$, and $e$ are model parameters; and $\ln$ is the natural logarithm. In model $5 i$ is species, $j$ is tree number, $f\left(\mathrm{Dbh}_{i j}, \mathrm{ht}_{i j}\right)$ is one of the model formulations $1-4, v_{i} \sim N\left(0, \sigma_{\mathrm{spe}}^{2}\right)$ is a random species effect, and $\varepsilon_{i j} s$ are random errors, $\varepsilon_{i j} \sim N\left(0, \sigma^{2}\right)$. Thus, for species groups, the between-species variation was modelled as a random effect.

Furthermore, to test the contribution of wood basic density in explaining the variation of biomass, the logarithmic version of the following power model $Y=\alpha \times$ $\left(w d \times \mathrm{Dbh}^{2} \times \mathrm{ht}\right)^{b}$ was tested:

(6) $\ln (Y)=a+b \times \ln \left(w d \times \mathrm{Dbh}^{2} \times \mathrm{ht}\right)$, where $w d$ is the wood basic density.

Prior to the regression analysis, dependent variables (volume and biomass) were plotted against each of the explanatory variables to examine the range and shape of the functional relationship and to assess the heterogeneity of the variance. Relationships were tested after transforming the variables. We selected our final models based on high adjusted $R^{2}$, low residual standard error (RMSE), and graphical analysis of the residuals. To assess the quality of the final models, we applied the approach also used by Chave et al. [25] and Djomo et al. [31], where the average percentage error between predicted and measured values is compared between the different equations after back-transforming to their original scale and correcting for logarithmic bias. The percentage error was calculated as

$$
100 \% \times \frac{Y_{\text {predicted }}-Y_{\text {measured }}}{Y_{\text {measured }}},
$$

where $Y$ is the biomass or volume of the tree. The correction factor $(\mathrm{CF})$ used for correcting for logarithmic bias was the one proposed by Sprugel [32], CF $=\exp \left(\mathrm{RMSE}^{2} / 2\right)$, which was applied to the predicted values of volume and biomass.

Finally, the average percentage error of the models prepared in this study was compared with that of ten previously published models when applied to the datasets from GVLFR. Correction for logarithmic bias was made in cases where dependent variables had been log-transformed. All analyses were made in Excel spreadsheets and R version 2.13.0 (http://www.r-project.org).

\section{Results}

3.1. Volume and Biomass Models. Selected models for total and stem volume and biomass of the three most dominant species are presented in Table 1. Similarly, Table 2 shows models for total and stem volume and biomass for the three species groups: shrubs, trees, and all species (trees and shrubs). The general tendency among the final models is that the fit improved when height and wood basic density were included in the model as indicated by the high adj. $R^{2}$, low residual standard error, and low average percentage error. However, the improvement of the fit achieved by including wood density was in most cases negligible and the performances of models 3 and 6 are therefore similar. As illustrated in Figure 2, the observations of total volume and biomass were nicely distributed around the values predicted by model 4 for shrubs, trees, and trees and shrubs combined and with only few outliers ending up outside (below) the 
TABLE 2: Volume and biomass equations for estimating total aboveground and stem $(\geq 5 \mathrm{~cm})$ volume and biomass of shrubs, trees, and woody plants in general (shrubs and trees) in Gangalamtumba Village Land Forest Reserve. A few estimates are not significantly different from zero $(P>0.05)$. These are marked "ns."

\begin{tabular}{|c|c|c|c|c|c|c|c|c|c|c|}
\hline \multirow{2}{*}{ Category } & \multirow{2}{*}{ Component } & \multirow{2}{*}{ Equation $^{\dagger}$} & \multicolumn{3}{|c|}{ Regression parameters } & \multirow{2}{*}{ Dbh range $(\mathrm{cm})$} & \multirow{2}{*}{$R_{L R}^{2}$} & \multirow{2}{*}{ RMSE } & \multirow{2}{*}{$\sigma_{\mathrm{spe}}$} & \multirow{2}{*}{ Avg. error (\%) } \\
\hline & & & $a$ & $b$ & $c$ & & & & & \\
\hline \multirow{9}{*}{$\begin{array}{l}\text { Shrubs } \\
(N=32) \\
16 \text { species }\end{array}$} & $\begin{array}{l}\text { Total volume } \\
\quad(\mathrm{df}=27)\end{array}$ & 3 & $\begin{array}{c}-8.3287 \\
(0.237)\end{array}$ & $\begin{array}{l}2.2340 \\
(0.099)\end{array}$ & $\begin{array}{c}0.0507^{\mathrm{ns}} \\
(0.206)\end{array}$ & $1.8-21.5$ & 0.979 & 0.251 & 0.00 & 18.48 \\
\hline & $(\mathrm{df}=28)$ & 4 & $\begin{array}{c}-8.2844 \\
(0.152)\end{array}$ & $\begin{array}{c}2.2517 \\
(2.252)\end{array}$ & - & $1.8-21.5$ & 0.979 & 0.247 & 0.00 & 18.57 \\
\hline & $\begin{array}{l}\text { Stem volume } \\
\qquad(\mathrm{df}=23)\end{array}$ & 3 & $\begin{array}{c}-13.4822 \\
(0.673)\end{array}$ & $\begin{array}{l}1.7917 \\
(0.316)\end{array}$ & $\begin{array}{l}2.8547 \\
(0.453)\end{array}$ & $5-21.5$ & 0.865 & 0.533 & 0.00 & 30.34 \\
\hline & $(\mathrm{df}=24)$ & 4 & $\begin{array}{c}-10.8001 \\
(0.710)\end{array}$ & $\begin{array}{l}2.6587 \\
(0.299)\end{array}$ & - & $5-21.5$ & 0.792 & 0.482 & 0.636 & 57.79 \\
\hline & $\begin{array}{l}\text { Total biomass } \\
\quad(\mathrm{df}=27)\end{array}$ & 3 & $\begin{array}{r}-1.8567 \\
(0.252)\end{array}$ & $\begin{array}{c}2.2145 \\
(0.106)\end{array}$ & $\begin{array}{c}0.1591^{\mathrm{ns}} \\
(0.219)\end{array}$ & $1.8-21.5$ & 0.977 & 0.267 & 0.00 & 21.90 \\
\hline & $(\mathrm{df}=28)$ & 4 & $\begin{array}{r}-1.7179 \\
(0.163)\end{array}$ & $\begin{array}{l}2.2697 \\
(0.073)\end{array}$ & - & $1.8-21.5$ & 0.977 & 0.265 & 0.00 & 22.43 \\
\hline & $(\mathrm{df}=28)$ & 6 & $\begin{array}{c}-8.6142 \\
(0.427)\end{array}$ & $\begin{array}{c}0.9417 \\
(0.034)\end{array}$ & - & $1.8-21.5$ & 0.968 & 0.266 & 0.184 & 18.93 \\
\hline & $\begin{array}{l}\text { Stem biomass } \\
\qquad(\mathrm{df}=23)\end{array}$ & 3 & $\begin{array}{c}-6.8855 \\
(0.639)\end{array}$ & $\begin{array}{l}1.9676 \\
(0.257)\end{array}$ & $\begin{array}{l}2.6083 \\
(0.428)\end{array}$ & $5-21.5$ & 0.916 & 0.390 & 0.276 & 29.50 \\
\hline & $(\mathrm{df}=24)$ & 4 & $\begin{array}{c}-4.3236 \\
(0.705) \\
\end{array}$ & $\begin{array}{l}2.6903 \\
(0.296) \\
\end{array}$ & - & $5-21.5$ & 0.799 & 0.470 & 0.676 & 56.02 \\
\hline \multirow{9}{*}{$\begin{array}{l}\text { Trees } \\
(N=72) \\
28 \text { species }\end{array}$} & $\begin{array}{l}\text { Total volume } \\
\quad(\mathrm{df}=69)\end{array}$ & 3 & $\begin{array}{c}-9.5238 \\
(0.075)\end{array}$ & $\begin{array}{c}1.8067 \\
(0.040)\end{array}$ & $\begin{array}{c}1.1940 \\
(0.076)\end{array}$ & $1.4-62$ & 0.997 & 0.129 & 0.00 & 1.66 \\
\hline & $(\mathrm{df}=70)$ & 4 & $\begin{array}{c}-8.4800 \\
(0.099)\end{array}$ & $\begin{array}{c}2.3351 \\
(0.033)\end{array}$ & - & $1.4-62$ & 0.986 & 0.219 & 0.179 & 6.46 \\
\hline & $\begin{array}{l}\text { Stem volume } \\
\qquad(\mathrm{df}=35)\end{array}$ & 3 & $\begin{array}{c}-11.0643 \\
(0.166)\end{array}$ & $\begin{array}{c}1.9316 \\
(0.079)\end{array}$ & $\begin{array}{l}1.5360 \\
(0.119)\end{array}$ & $5-62$ & 0.994 & 0.162 & 0.00 & 4.55 \\
\hline & $(\mathrm{df}=35)$ & 4 & $\begin{array}{c}-10.9307 \\
(0.273)\end{array}$ & $\begin{array}{c}3.0134 \\
(0.093)\end{array}$ & - & $5-62$ & 0.975 & 0.317 & 0.119 & 13.10 \\
\hline & $\begin{array}{l}\text { Total biomass } \\
\qquad(\mathrm{df}=69)\end{array}$ & 3 & $\begin{array}{c}-3.1399 \\
(0.123)\end{array}$ & $\begin{array}{l}1.7586 \\
(0.057)\end{array}$ & $\begin{array}{l}1.2934 \\
(0.115)\end{array}$ & $1.4-62$ & 0.992 & 0.118 & 0.278 & 2.47 \\
\hline & $(\mathrm{df}=70)$ & 4 & $\begin{array}{c}-2.0667 \\
(0.124)\end{array}$ & $\begin{array}{c}2.3561 \\
(0.036)\end{array}$ & - & $1.4-62$ & 0.979 & 0.213 & 0.392 & 9.96 \\
\hline & $(\mathrm{df}=70)$ & 6 & $\begin{array}{c}-9.1880 \\
(0.101)\end{array}$ & $\begin{array}{l}0.9668 \\
(0.007)\end{array}$ & - & $1.4-62$ & 0.996 & 0.131 & 0.052 & 1.32 \\
\hline & $\begin{array}{l}\text { Stem biomass } \\
\qquad(\mathrm{df}=37)\end{array}$ & 3 & $\begin{array}{c}-5.6032 \\
(0.326)\end{array}$ & $\begin{array}{l}2.1420 \\
(0.158)\end{array}$ & $\begin{array}{l}1.7090 \\
(0.269)\end{array}$ & $5-62$ & 0.965 & 0.294 & 0.221 & 6.30 \\
\hline & $(\mathrm{df}=38)$ & 4 & $\begin{array}{c}-4.4622 \\
(0.365) \\
\end{array}$ & $\begin{array}{l}2.9972 \\
(0.120) \\
\end{array}$ & - & $5-62$ & 0.928 & 0.387 & 0.375 & 10.60 \\
\hline \multirow{6}{*}{$\begin{array}{l}\text { Combined } \\
(N=104) ; \\
44 \text { species }\end{array}$} & $\begin{array}{l}\text { Total volume } \\
\quad(\mathrm{df}=100)\end{array}$ & 3 & $\begin{array}{c}-9.0339 \\
(0.104)\end{array}$ & $\begin{array}{c}1.9637 \\
(0.053)\end{array}$ & $\begin{array}{l}0.7737 \\
(0.103)\end{array}$ & $1.4-62$ & 0.989 & 0.193 & 0.131 & 6.54 \\
\hline & $(\mathrm{df}=101)$ & 4 & $\begin{array}{c}-8.4554 \\
(0.084)\end{array}$ & $\begin{array}{l}2.3236 \\
(0.031)\end{array}$ & - & $1.4-62$ & 0.983 & 0.248 & 0.140 & 9.89 \\
\hline & $\begin{array}{l}\text { Stem volume } \\
\quad(\mathrm{df}=42)\end{array}$ & 3 & $\begin{array}{c}-12.2617 \\
(0.244)\end{array}$ & $\begin{array}{c}2.1378 \\
(0.127)\end{array}$ & $\begin{array}{l}1.7695 \\
(0.203)\end{array}$ & $5-62$ & 0.977 & 0.271 & 0.153 & 18.50 \\
\hline & $(\mathrm{df}=43)$ & 4 & $\begin{array}{c}-11.1929 \\
(0.339)\end{array}$ & $\begin{array}{l}3.0514 \\
(0.115)\end{array}$ & - & $5-62$ & 0.935 & 0.413 & 0.327 & 49.22 \\
\hline & $\begin{array}{l}\text { Total biomass } \\
\qquad(\mathrm{df}=100)\end{array}$ & 3 & $\begin{array}{c}-2.6896 \\
(0.131)\end{array}$ & $\begin{array}{c}1.9041 \\
(0.064)\end{array}$ & $\begin{array}{l}0.9377 \\
(0.128)\end{array}$ & $1.4-62$ & 0.983 & 0.182 & 0.317 & 8.96 \\
\hline & $(\mathrm{df}=101)$ & 4 & $\begin{array}{c}-1.9564 \\
(0.102)\end{array}$ & $\begin{array}{l}2.3260 \\
(0.035)\end{array}$ & - & $1.4-62$ & 0.974 & 0.242 & 0.327 & 12.60 \\
\hline
\end{tabular}


TABLE 2: Continued.

\begin{tabular}{|c|c|c|c|c|c|c|c|c|c|c|}
\hline \multirow{2}{*}{ Category } & \multirow{2}{*}{ Component } & \multirow{2}{*}{ Equation $^{\dagger}$} & \multicolumn{3}{|c|}{ Regression parameters } & \multirow{2}{*}{ Dbh range $(\mathrm{cm})$} & \multirow{2}{*}{$R_{\mathrm{LR}}^{2}$} & \multirow[t]{2}{*}{ RMSE } & \multirow{2}{*}{$\sigma_{\text {spe }}$} & \multirow{2}{*}{ Avg. error (\%) } \\
\hline & & & $a$ & $b$ & $c$ & & & & & \\
\hline & $(\mathrm{df}=101)$ & 6 & $\begin{array}{c}-8.8819 \\
(0.139)\end{array}$ & $\begin{array}{l}0.9497 \\
(0.010)\end{array}$ & - & $1.4-62$ & 0.988 & 0.187 & 0.162 & 6.40 \\
\hline & $\begin{array}{c}\text { Stem biomass } \\
\quad(\mathrm{df}=42)\end{array}$ & 3 & $\begin{array}{c}-5.9897 \\
(0.279)\end{array}$ & $\begin{array}{l}2.0894 \\
(0.146)\end{array}$ & $\begin{array}{l}1.9457 \\
(0.238)\end{array}$ & $5-62$ & 0.970 & 0.290 & 0.230 & 13.70 \\
\hline & $(\mathrm{df}=43)$ & 4 & $\begin{array}{c}-4.8335 \\
(0.349)\end{array}$ & $\begin{array}{l}3.0979 \\
(0.117)\end{array}$ & - & $5-62$ & 0.924 & 0.383 & 0.488 & 43.10 \\
\hline & $(\mathrm{df}=43)$ & 6 & $\begin{array}{c}-13.5156 \\
(0.455)\end{array}$ & $\begin{array}{l}1.2284 \\
(0.032)\end{array}$ & - & $5-62$ & 0.971 & 0.314 & 0.153 & 25.10 \\
\hline
\end{tabular}

Note: numbers in brackets indicate standard errors of the estimates. Height range: shrubs $2.5-8 \mathrm{~m}$; trees: $2.5-18.2 \mathrm{~m}$; and combined: $2.5-18.2 \mathrm{~m}$. df is degrees of freedom; RMSE is standard error of the residuals; $\sigma_{\text {spe }}$ is the standard deviation of the species random effect (between-species variation); $R^{2}{ }_{L R}$ is the likelihood ratio based coefficient of determination; and Avg. is Average. ${ }^{\dagger}$ Equation (3): $\ln (Y)=a+b \ln (\mathrm{Dbh})+c \ln (\mathrm{ht})$. Equation (4): $\ln (Y)=a+b \ln (\mathrm{Dbh})$. Equation (6): $\ln (Y)=a+b \ln \left(\mathrm{wdDbh}^{2} \mathrm{ht}\right) ; Y$ is volume $\left(\mathrm{m}^{3}\right)$ or biomass $(\mathrm{kg})$; Dbh is diameter at breast height $(\mathrm{cm})$; ht is total height $(\mathrm{m})$; and wd is wood density $\left(\mathrm{kg} \mathrm{m}^{-3}\right)$.

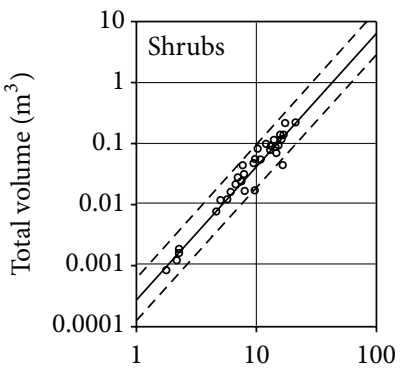

Diameter at breast height $(\mathrm{cm})$

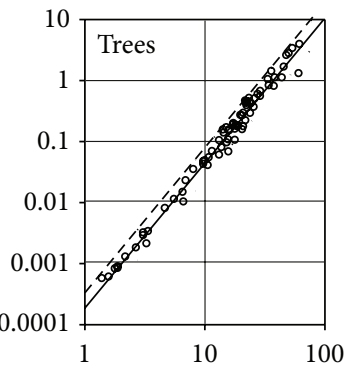

Diameter at breast height $(\mathrm{cm})$

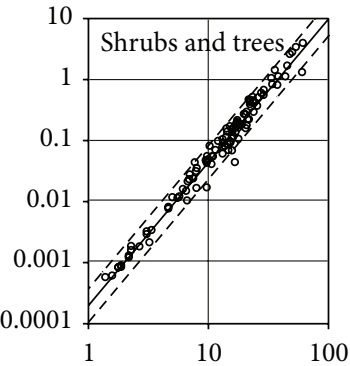

Diameter at breast height $(\mathrm{cm})$

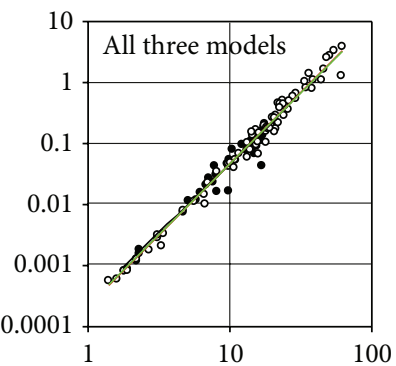

Diameter at breast height $(\mathrm{cm})$

- Obs., shrubs — Model, trees

- Obs., trees Model, both

- Model, shrubs

(a)
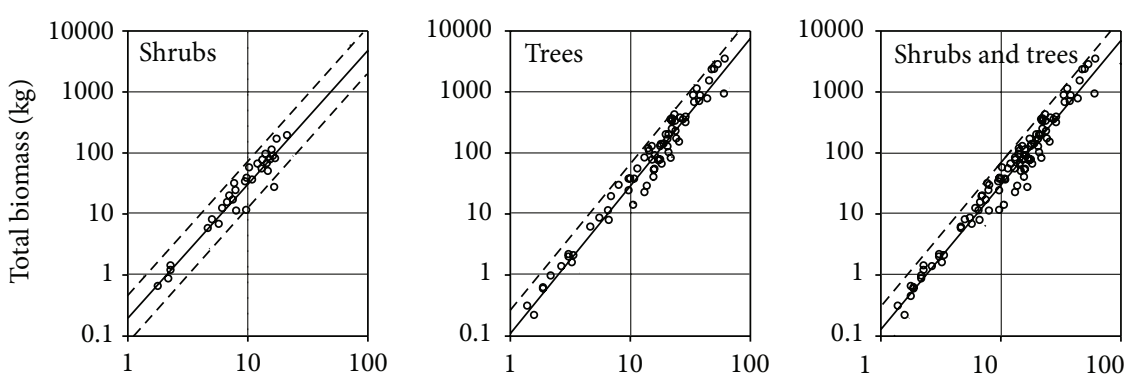

Diameter at breast height $(\mathrm{cm})$ Diameter at breast height $(\mathrm{cm})$

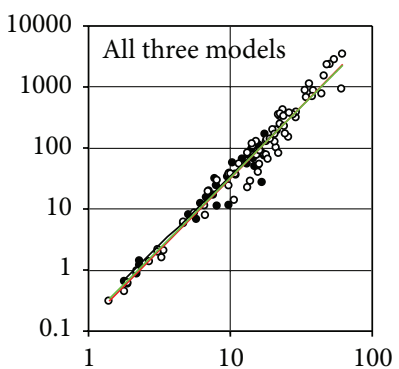

Diameter at breast height $(\mathrm{cm})$

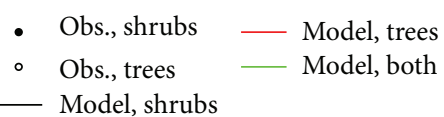

(b)

FIgURE 2: Model 4 for total volume (a) and biomass (b) of the three species groups: shrubs, trees, and shrubs and trees. First three columns: circles indicate observed values, unbroken lines show expected values, and dashed lines are 95\% prediction intervals; fourth column: all three models (see legend).

95\% prediction intervals. Furthermore, the graphs in Figure 2 illustrate that the differences between values predicted by models for the three life form groups are limited.

3.2. Model Performance. To some extent the overall performance of the volume and biomass models can be judged from the RMSE and $R^{2}$ values reported in Tables 1 and 2. In addition to these measures, both tables report the average percentage error after correction for logarithmic bias. As expected, species-specific models (Table 1) turned out to have lower average percentage error compared to models developed for the broader species groups (trees, shrubs, and 
trees and shrubs combined); see Table 2. When comparison was made between the average percentage error obtained by using species-specific models for volume and biomass prediction in the individual species datasets and the corresponding values obtained for the general, mixed species-group models (models prepared for trees applied to B. spiciformis and C. molle and models prepared for shrubs applied to D. arbutifolia), it emerged that the individual species-specific models produced considerably lower average percentage errors than the mixed species-group models (results not shown). A similar pattern was observed when models calibrated for trees and shrubs were applied to datasets including either trees or shrubs alone. For both volume and biomass, it emerged that model 4, which includes only one independent variable (Dbh), was characterised by larger average percentage errors than model 3 which includes two independent variables (Dbh and ht). Also, inclusion of wood basic density in the models (model 6) tended to improve the fit significantly as indicated by the high adj. $R^{2}$ and low residual standard error.

\section{Discussion}

The new volume and biomass models for individual species and for broader species groups (shrubs, trees, and both) provide a comprehensive range of tools for estimation of standing volume, aboveground biomass, and carbon stock of dry miombo vegetation in Tanzania. Since the number of sample trees and shrubs for the general model is relatively large and includes a large number of species (44 different species) compared to site-specific models reported elsewhere [13-15], the newly developed models are likely to be quite robust and can presumably be applied in areas with similar site conditions with only a limited increase of bias compared to locally calibrated models.

Not surprisingly, the species-specific volume and biomass models were superior to models prepared for species groups in terms of average percentage error. Similarly, models prepared for individual species groups (trees and shrubs separately) were superior to models prepared for the combined dataset including both trees and shrubs. Thus, the precision and accuracy of the predictions tends to increase from general (all species, trees, and shrubs) to species-specific (single species) models.

To assess the increase in accuracy achieved in GVLFR by the new models, 10 different previously published volume and biomass models for miombo woodlands were tested on the datasets prepared in this study. The models include five volume functions and five biomass functions and the calculated average percentage error obtained for each combination of model and dataset is shown in Table 3. In each case, model predictions were corrected for logarithmic bias, except for models 8,9 , and 16 , for which no residual standard deviation (RMSE) was provided, and models 12, 13,14 , and 15 which are power models. When comparing the average percentage errors obtained for our models with those of the existing models, it turned out that both our species-specific models (Table 1) and species-group models (Table 2) yielded relatively low average percentage errors compared to the existing models. However, based on the average percentage errors, it also appeared that models 8,9 , 10 , and 11 produced the most accurate estimates of volume for shrubs and, similarly, that models 9 and 10 yielded the lowest average percentage errors for volume in the combined dataset (trees and shrubs). Except for models prepared for the shrub species group (Table 2), which are characterised by relatively high average percentage errors, models prepared in this study produced better estimates of biomass with lower average percentage errors than the existing models. In part, this is a consequence of calibrating and testing our models on the same dataset, but it may also be related to the fact that the diameter ranges of the datasets applied in this study are considerably broader than those of the datasets used for calibrating the existing models from the literature. Mugasha et al. [15] observed a similar pattern of improved accuracy and precision of the predictions when comparing site-specific models to a general model. However, as shown in Table 3 models 14 and 15 (biomass) seem to work very well on the shrub dataset and the C. molle (tree) and D. arbutifolia (shrub) datasets as they are characterised by relatively low average percentage errors.

Considering the high species diversity found in the miombo woodlands, the variation of species composition from site to site, and the impact of site conditions on the shape of trees, the use of mixed-species regression models calibrated on data from sites with similar site conditions and species composition is a logical choice. By contrast, general allometric equations developed in other regions with different species composition should be used with caution and only if local mixed-species models are not available. Locally abundant species would usually not be represented in the databases used for development of such general allometric models and they therefore may not accurately reflect the true biomass of trees in a given forest area $[1,31,33]$. Therefore, the use of site-specific models is recommended to ensure that high precision is achieved in quantification of woodland resources [15].

The large percentage errors observed for the shrub dataset are presumably caused by the large variation of physical shapes characterising this category of woody plants. The dataset included 16 different shrub species, and some of them are characterised by very special stem and crown shapes and very low (or high) wood basic densities. This could explain the large variation observed in the volume and biomass for stems.

The value of species-specific models as a way to minimise variation and increase the accuracy of models should not go unmentioned. However, as explained, the high diversity of species in miombo woodlands and in most other tropical forest types combined with frequent challenges of correct botanical identification enhances the cost of preparing species-specific models with a view to improve the accuracy of standing volumes and biomass estimates at the forest level. Mixed-species models are, therefore, still useful but they should be applied with due consideration of the improved quality of volume/biomass estimates that can be obtained by the application of species-specific models. 


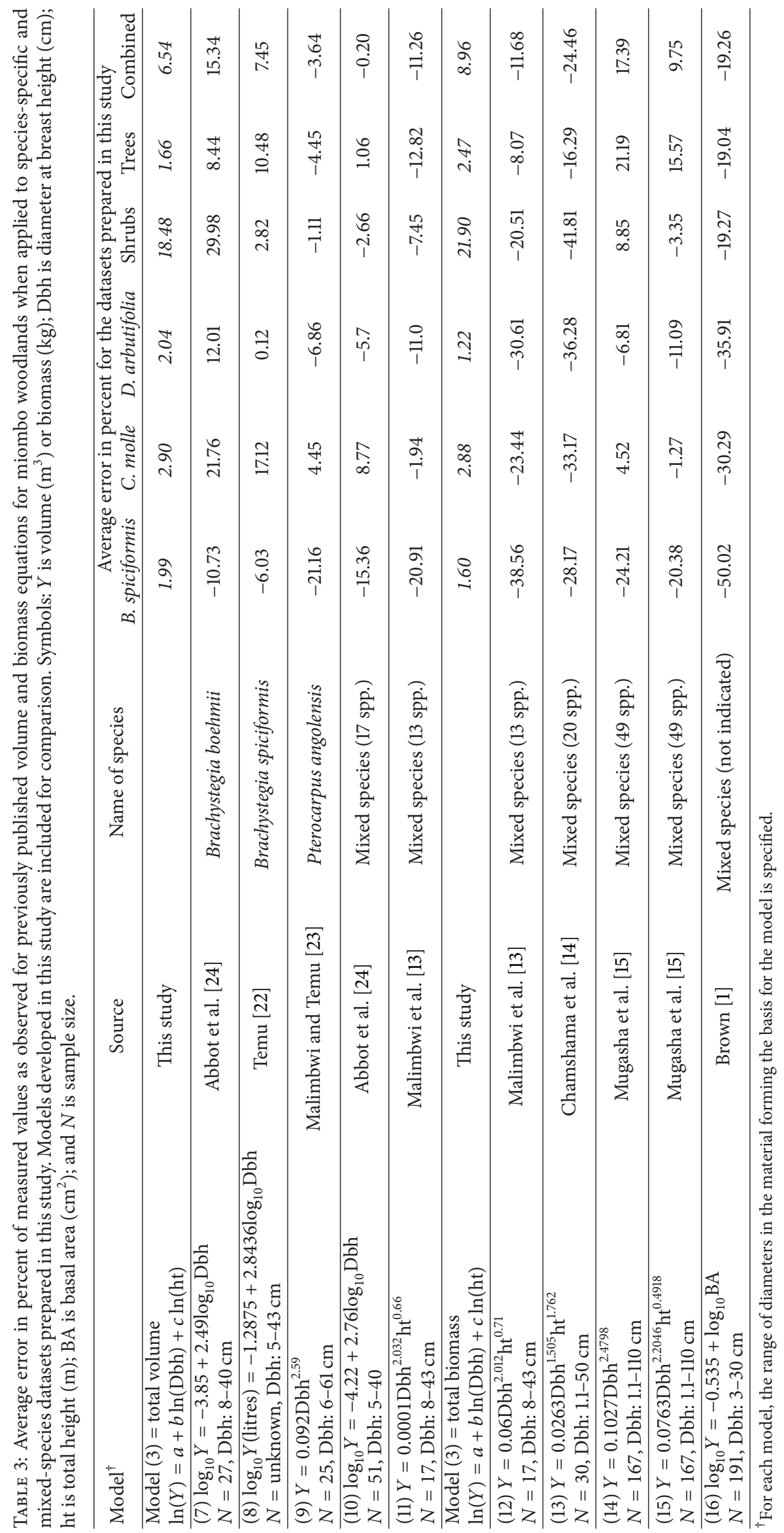




\section{Conclusion}

This study for the first time provides a comprehensive pool of different allometric equations for estimating total and stem volume and biomass, for (i) selected individual species and (ii) for mixed-species groups found in the dry miombo woodlands of Tanzania. Since most of the models have higher $R^{2}$, lower RMSE, and lower average percentage error than the existing equations, these new models should be useful for providing reliable estimates of volume and biomass for forests with similar species composition and site conditions (soil and climate). Furthermore, the new models can be applied at all levels from the species-specific, individual-tree level to the stand level. Modelling the volume and biomass of shrubs turned out to be challenging, possibly due to the large variation of wood density and shape of stem and crown characterising this group. Further research on measures that could be used to improve volume and biomass estimates for shrubs would therefore be useful.

\section{Conflict of Interests}

The authors declare that there is no conflict of interests regarding the publication of this paper.

\section{Acknowledgments}

Special thanks are due to the people of Mfyome village for their invaluable assistance during the field work: Mzee Iddi Kaheya, Damian Chotamasege, Augustino Mkwama, Ibrahim Mbilinyi, Liberatus Simime, Mawazo Nyangwa, Thomas Kivamba, and Lutengano Anangisye. The authors gratefully acknowledge the help and contributions of Goodluck Moshi, their driver, Venancia Mlelwa, John Shesighe and Tulamwona Ernest at Sokoine University of Agriculture who did most of the laboratory work, Nassoro H. Magogo at Tanzania Forest Research Institute's herbarium in Lushoto who did the botanical identification work, and Klaus Dons at Forest \& Landscape who prepared the map of the study site in Figure 1. Finally, the Danish Ministry of Foreign Affairs (Danida) supported the work financially through the ENRECA project, "Participatory Forest Management for Rural Livelihoods, Forest Conservation and Good Governance in Tanzania" (Grant no. 725).

\section{References}

[1] S. Brown, "Estimating biomass and biomass change of tropical forests: a primer," FAO Forest Paper 134, 1997.

[2] T. J. Brandeis, M. Delaney, B. R. Parresol, and L. Royer, "Development of equations for predicting Puerto Rican subtropical dry forest biomass and volume," Forest Ecology and Management, vol. 233, no. 1, pp. 133-142, 2006.

[3] B. Husch, T. W. Beers, and J. A. Kershaw, Forest Mensuration, John Wiley \& Sons, Hoboken, NJ, USA, 4th edition, 2003.

[4] P. H. Freer-Smith, M. S. J. Broadmeadow, and J. M. Lynch, Forestry \& Climate Change, Forestry Research, Farnham, UK, 2007.
[5] A. de Gier, "A new approach to woody biomass assessment in woodlands and shrublands," in GeoinFormatics for Tropical Ecosystems, P. S. Roy, Ed., pp. 161-198, Bishen Singh Mahendra Pal Singh, Dehradun, India, 2003.

[6] J. Navar, "measurement and assessment methods of forest aboveground biomass: a literature review and the challenges ahead," in Biomass, M. Momba and F. Bux, Eds., pp. 27-64, publisher Janeza Trdine, Rijeka, Croatia, 2010, http://www.sciyo.com.

[7] M. Williams, C. M. Ryan, R. M. Rees, E. Sambane, J. Fernando, and J. Grace, "Carbon sequestration and biodiversity of regrowing miombo woodlands in Mozambique," Forest Ecology and Management, vol. 254, no. 2, pp. 145-155, 2008.

[8] M. De Ridder, W. Hubau, J. van den Bulcke, J. van Acker, and H. Beeckman, "The potential of plantations of Terminalia superba engl. \& diels for wood and biomass production (Mayombe Forest, Democratic Republic of Congo)," Annals of Forest Science, vol. 67, no. 5, pp. 501-512, 2010.

[9] S. Brown, "Measuring, monitoring, and verification of carbon benefits for forest-based projects," Philosophical Transactions of the Royal Society A, vol. 360, no. 1797, pp. 1669-1683, 2002.

[10] M. Henry, N. Picard, C. Trotta et al., "Estimating tree biomass of sub-Saharan African forests: a review of available allometric equations," Silva Fennica, vol. 45, no. 3, pp. 477-569, 2011.

[11] O. Hofstad, "Review of biomass and volume functions for individual trees and shrubs in Southeast Africa," Journal of Tropical Forest Science, vol. 17, no. 1, pp. 151-162, 2005.

[12] C. M. Ryan, M. Williams, and J. Grace, "Above- and belowground carbon stocks in a miombo woodland landscape of mozambique," Biotropica, vol. 43, no. 4, pp. 423-432, 2011.

[13] R. E. Malimbwi, B. Solberg, and E. Luoga, "Estimation of biomass and volume in miombo woodland at Kitulangalo Forest Reserve, Tanzania," Journal of Tropical Forest Science, vol. 7, no. 2, pp. 230-242, 1994.

[14] S. A. O. Chamshama, A. G. Mugasha, and E. Zahabu, "Stand biomass and volume estimation for Miombo woodlands at Kitulangalo, Morogoro, Tanzania," Southern African Forestry Journal, no. 200, pp. 59-69, 2004.

[15] W. A. Mugasha, T. Eid, O. M. Bollandsas et al., "Allometric models for prediction of above- and below ground biomass of trees in the miombo woodlands of Tanzania," Forest Ecology and Management, vol. 310, pp. 87-101, 2013.

[16] N. Calender, "Miombo woodland-distribution, ecology and patterns of land use," Working Paper 16, Swedish University of agricultural Sciences, Uppsala, Sweden, 1981.

[17] E. N. Chidumayo, "Estimating fuelwood production and yield in regrowth dry miombo woodland in Zambia," Forest Ecology and Management, vol. 24, no. 1, pp. 59-66, 1988.

[18] D. D. Shirima, P. K. T. Munishi, S. L. Lewis et al., "Carbon storage, structure and composition of miombo woodlands in Tanzania’s Eastern Arc Mountains," African Journal of Ecology, vol. 49, no. 3, pp. 332-342, 2011.

[19] Q. M. Ketterings, R. Coe, M. Van Noordwijk, Y. Ambagau', and C. A. Palm, "Reducing uncertainty in the use of allometric biomass equations for predicting above-ground tree biomass in mixed secondary forests," Forest Ecology and Management, vol. 146, no. 1-3, pp. 199-209, 2001.

[20] H. K. Gibbs, S. Brown, J. O. Niles, and J. A. Foley, "Monitoring and estimating tropical forest carbon stocks: making REDD a reality," Environmental Research Letters, vol. 2, no. 4, Article ID 045023, 2007. 
[21] M. A. Pinard and F. E. Putz, "Retaining forest biomass by reducing logging damage," Biotropica, vol. 28, pp. 278-295, 1996.

[22] A. B. Temu, "Double sampling with aerial photographs in estimating wood volume in miombo woodlands," Division of Forestry, University of Dar-es-Salaam, Morogoro, Tanzania, vol. 22, pp. 1-17, 1981.

[23] R. E. Malimbwi and A. B. Temu, "Volume functions for Pterocarpus angolensis and Julbernadia globiflora," Journal of Tanzania Association of Foresters, vol. 1, pp. 49-53, 1984.

[24] P. Abbot, J. Lowore, and M. Werren, "Models for the estimation of single tree volume in four Miombo woodland types," Forest Ecology and Management, vol. 97, pp. 25-37, 1997.

[25] J. Chave, C. Andalo, S. Brown et al., "Tree allometry and improved estimation of carbon stocks and balance in tropical forests," Oecologia, vol. 145, no. 1, pp. 87-99, 2005.

[26] M. Henry, A. Besnard, W. A. Asante et al., "Wood density, phytomass variations within and among trees, and allometric equations in a tropical rainforest of Africa," Forest Ecology and Management, vol. 260, no. 8, pp. 1375-1388, 2010.

[27] LIFE and SUA, "Participatory Forest Management: inception report," Sokoine University of Agriculture (SUA), Faculty of Forestry and Nature Conservation (FFNC), University of Copenhagen, Forest \& Landscape Denmark (FLD), Cambridge University, Cambridge, UK, University of Manchester, Manchester, UK, 2007.

[28] H. T. Valentine, L. M. Tritton, and G. M. Furnival, "Subsampling trees for biomass, volume, or mineral content," Forest Science, vol. 30, no. 3, pp. 673-681, 1984.

[29] P. O. Olesen, "The water displacement method. A fast and accurate method of determining the green volume of wood samples," Forest Tree Improvement, vol. 3, pp. 1-23, 1971.

[30] E. E. Mwakalukwa, H. Meilby, and T. Treue, "Wood basic densities of dry miombo woodland trees and shrubs in Tanzania," In press.

[31] A. N. Djomo, A. Ibrahima, J. Saborowski, and G. Gravenhorst, "Allometric equations for biomass estimations in Cameroon and pan moist tropical equations including biomass data from Africa," Forest Ecology and Management, vol. 260, no. 10, pp. 1873-1885, 2010.

[32] D. G. Sprugel, "Correcting for bias in log- transformed allometric equations," Ecology, vol. 64, no. 1, pp. 209-210, 1983.

[33] J. Návar, "Biomass component equations for Latin American species and groups of species," Annals of Forest Science, vol. 66, no. 2, p. 208, 2009. 

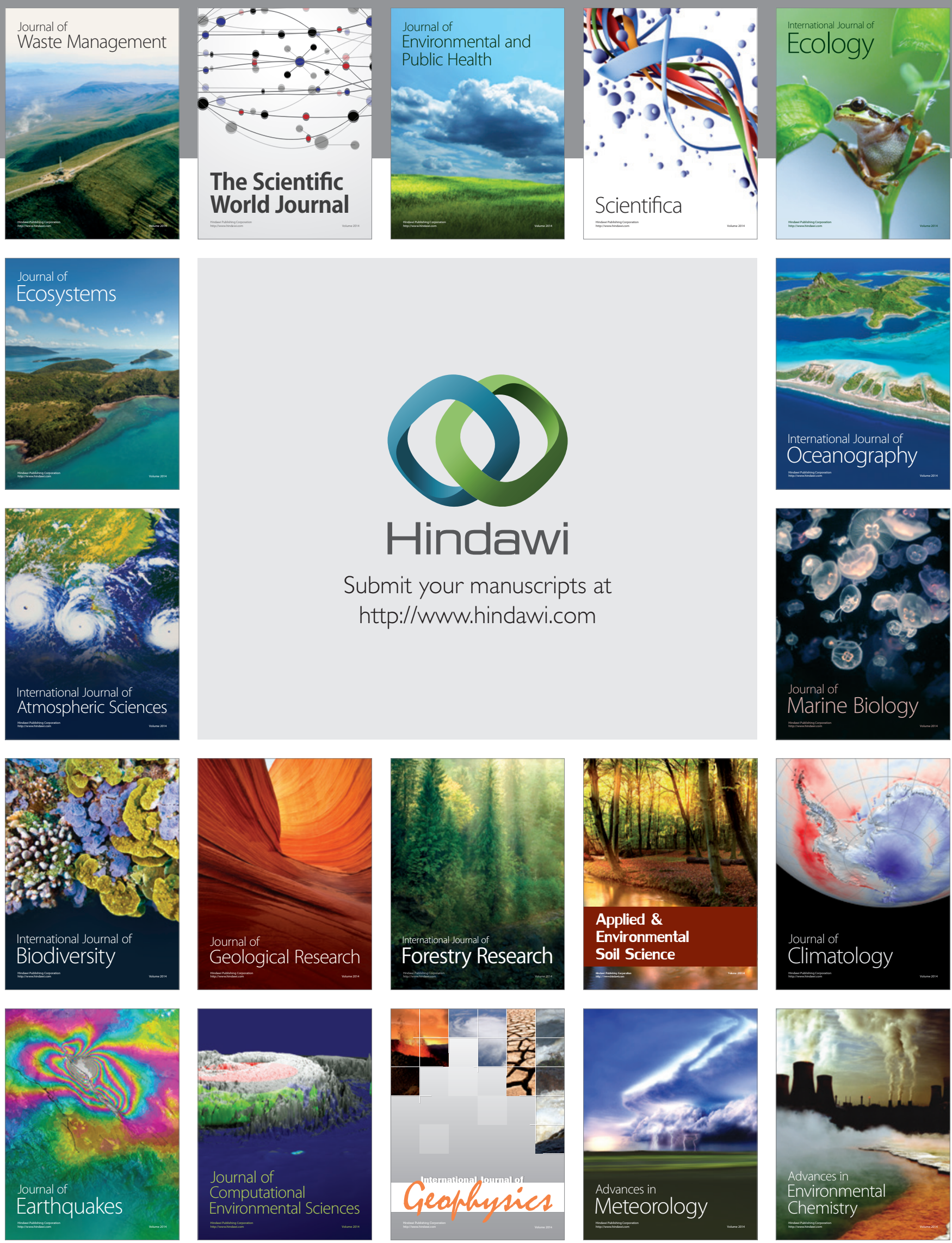